\title{
Effect of Long-Term Agricultural Management Systems on OCCURRENCE AND COMPOSITION OF WEED SPECIES ${ }^{1}$
}

\author{
Efeito do Manejo de Longo Prazo em Sistemas Agrícolas Sobre a Ocorrência e Composição de \\ Espécies Daninhas
}

\author{
CONCENÇO, G. ${ }^{2}$, SALTON, J.C. ${ }^{3}$, SECRETTI, M.L. ${ }^{4}$, MENDES, P.B. ${ }^{5}$, BREVILIERI, R.C. ${ }^{6}$ and \\ GALON, L. ${ }^{7}$
}

\begin{abstract}
This study aims to assess the composition of weed communities as a function of distinct selection factors, at neighboring areas submitted to distinct soil management and diverse use for sixteen years. Four areas submitted to distinct managements (conventional tillage system; no-till system; integration crop/livestock and continuous livestock) were sampled in relation to the occurrence and severity of weed species by the beginning of the planting season, being estimated the relative abundance, relative frequency and relative dominance of each weed species under each area, as well as the Importance Value Index for each species. Areas were also compared by the Sørensen's similarity coefficient. Areas where pasture and grazing were never present, exhibited a number of seedlings of weed species $250 \%$ higher than areas periodically or continuously under grazing, while the area of soil covered by weeds was $87 \%$ superior at the conventional tillage system in relation to the average of the other treatments. Grass weeds were the most important at the conventional tillage area while broadleaved weeds where more important at the no-till area, probably due also to herbicide selection factors. Under crop/livestock integration there may be the need to care about controlling seedlings of the forage species inside grain crops in succession.
\end{abstract}

Keywords: integration crop/livestock, cropping systems, phytosociology.

\begin{abstract}
RESUMO - Objetivou-se com este estudo avaliar a composição de comunidades infestantes em função de distintos fatores de seleção, em áreas vizinhas submetidas a distintos manejos de solo e usos por 16 anos. Quatro áreas submetidas a manejos distintos (sistema de cultivo convencional, sistema plantio direto, integração lavoura/pecuária e pecuária continua) foram amostradas em relação a ocorrência e severidade de espécies de plantas daninhas no início da estação de cultivo, sendo estimadas a abundância relativa, frequência relativa e dominância relativa de cada espécie daninha em cada área, bem como o Índice de Valor de Importância para cada espécie. As áreas também foram comparadas pelo coeficiente de similaridade de Sørensen. Áreas onde forragens e pastejo não estão inseridas na rotação apresentaram número de plântulas de espécies daninhas $250 \%$ superior em relação a áreas periodicamente ou continuamente sob pastejo, enquanto a área de solo coberta pela comunidade de plantas infestantes foi $87 \%$ superior no tratamento com preparo convencional do solo, em relação a média dos demais tratamentos. Plantas daninhas de folhas estreitas foram predominantes na área de preparo convencional do solo enquanto folhas largas predominaram na área de plantio direto, provavelmente devido também a fatores de seleção relativos ao herbicida. Na área de integração lavoura/pecuária pode haver a necessidade de controle de plântulas da espécie semeada como forrageira durante o cultivo em sucessão a pastagem.
\end{abstract}

Palavras-chave: integração lavoura/pecuária, sistemas de cultivo, fitossociologia.

1 Recebido para publicação em 18.2.2011 e aprovado em 25.4.2011.

${ }^{2}$ Agronomist, Ph.D. in Weed Science, researcher at Embrapa Western Agriculture - CPAO, Dourados-MS, Brazil, <germani@cpao.embrapa.br>; ${ }^{3}$ Agronomist, Ph.D. in Soil Science, researcher at Embrapa CPAO, Dourados-MS, Brazil; ${ }^{4}$ Undergraduate student of Agronomy of the Universidade Estadual de Mato Grosso do Sul - UEMS, Mato Grosso do Sul-MS, trainee at Embrapa CPAO; ${ }^{5}$ Undergraduate student at Centro Universitário da Grande Dourados - UNIGRAN, Dourados-MS, Brazil, trainee at Embrapa CPAO; ${ }^{6}$ Master student of Soil Science, UEMS; ${ }^{7}$ Agronomist, Ph.D in Weed Science, professor at Universidade Federal do Pampa - UNIPAMPA, Itaqui-RS, Brazil.

Planta Daninha, Viçosa-MG, v. 29, n. 3, p. 515-522, 2011 


\section{INTRODUCTION}

Studies related to weed behavior are essential for agriculture sustainability in tropical soils, once their interference can cause significant yield losses, especially in crops with lower competitive ability. One of the mechanisms which ensures survival of a given species under constantly disturbed environments, especially for annual plants, is the high number of seeds produced. Deuber (1992) cites several weeds with high seed production, as Amaranthus spp. 120.000 seeds per plant, Galinsoga parviflora -30.000 seeds per plant and Portulaca oleracea - 53.000 seedsper plant. In an adverse and constantly disturbed environment these species usually tend to increase its occurrence, covering most of the area and causing more problems for commercial crops. In addition, factors related to herbicide tolerance may contribute for the higher occurrence of a given weed species (Norsworthy et al., 2001).

Among distinct soil managements, no-till cropping systems can shift the dynamics of weed species at the soil seed bank and also modify the effectiveness of soil-applied herbicides, due to soil coverage and possible herbicide interception by crop residues (Bulher et al., 1996). In this way, even shifting the number and composition of weeds, some species may be more difficult to control under no-till systems than under conventional tillage systems (Gomes \& Christoffoleti, 2008).

In addition, distinct cropping systems affect weed composition and its occurrence by changing the pool of management practices applied to the area, which will change the nature and amount of resources available for weeds, and help excluding from the system those weed species highly specialized in exploring a single of a few environmental resources, opening space for less specialized and more flexible plant species (Gurevitch et al., 2009), which are usually not troublesome weeds.

Understanding not only the level of occurrence but also the composition of the weed community under each cropping system is important to achieve efficient control. Research data shows that management systems with low soil disturbance allow formation of a bigger and more diverse weed seed bank in soil. We hypothesize that under no-till systems and integration crop-livestock, the presence of straw from previous crops, as well as the integrated set of weed management practices, is important for reducing the emergence percentage of some weed species while it may increase the occurrence of others.

Besides cropping systems, recent publications point a closer integration between crop and livestock production under no-till systems, as the basis for sustainability of agribusiness at the Cerrado region of Brazil (Voll et al., 2005). Among several advantages of this integration, the reduction in occurrence of weed species can be highlighted by reducing the soil seed bank more efficiently than when using only herbicides for weed control - which usually does not affect dormant seeds in soil. In addition, this integration makes possible to manage the resistance of some weeds to herbicides, once grazing is almost a nonselective method of weed control (Voll et al., 2005).

Phytosociological studies allow assessing species composition of a given canopy and their estimation of frequency, relative frequency, density, relative density, abundance, relative abundance and relative importance index for each species in the community, supporting inferences about a given group of plants (Gomes et al., 2010). In addition, it is possible to compare distinct areas under the same edapho-climatic conditions by using the Sørensen's similarity coefficient (Sørensen, 1957).

This study aims to assess the composition of weed communities as a function of distinct selection factors, at neighboring areas submitted to distinct soil management and diverse use for sixteen years.

\section{MATERIAL AND METHODS}

The trial comprises an area of 28 ha of a clayey Oxisoil and was installed in 1995 at the experimental Station owned by Embrapa Western Region Agriculture, Dourados city, Mato Grosso do Sul state, Brazil. Geographical coordinates of the long-term trial are $22^{\circ} 14^{\prime}$ 'S $-54^{\circ} 49^{\prime} \mathrm{W}$ with $430 \mathrm{~m}$ of altitude. A complete 
survey about soil class can be found in Amaral et al. (2000).

Before implementation of the trial, the area was used for grain crops under conventional soil tillage since the 70's. This site is in a transitional area between the Cerrado and the Atlantic Forest biomes, and climate in this region according to Köpen classification is Cwa mesothermal humid climate, with hot summers and dry winters (Fietz \& Fisch, 2006).

Distinct soil and cropping management systems were implemented in 1995 and since then these areas have been managed as follows:

L-PC: Grain crops grown under conventional soil tillage, with monoculture of soybeans at the summer and oats in the winter time; soil tillage is done by harrowing in a plot of 2 hectares (ha);

L-PD: Grain crops grown under zero soil tillage in an area of 6 ha, with crop rotation including soybean and corn grown in two hectares for each one in summer. During the fall-winter and spring time, wheat and oats are planted for grains, and oats and turnip are planted for straw deposition, keeping the sequence: ... / oilseed radish/corn/oat/ soybean/ wheat/soybean/...

S2P2: Rotation crop/livestock: Switching between crops (soybean/oats) and pasture (Brachiaria decumbens) conducted under zero tillage, cycling every two years. Each subplot covers 4 ha, in a total of 8 hectares, and pastures are grazed by Nelore cattle with stocking rate adjusted to maintain a constant supply of forage of around 7\% (7 kg of dry mass for $100 \mathrm{~kg}$ of living animals per day). Soil fertilization or liming are done only in grain crops along the crop rotation.

PP: Continuous livestock: Area of 4 ha where Brachiaria decumbens is grown under rotational grazing, with the number of animals adjusted to keep constant forage supply of around 7\%. This forage area was installed in 1995 and no fertilizer or lime were applied.

The Chemical analysis of soil is presented in Table 1 with the concentrations of major elements in the layers 0-5 and 5-15 cm depth.

Phytosociological characterization of weed species emerged from soil seed bank was carried out in each one of the four previously characterized areas. For that, four areas of $2500 \mathrm{~cm}^{2}$ in each management system were sampled by the time of crop planting (beginning of summer). In each sampled area all the emerged seedlings were identified, collected and stored by species, being dried for posterior dry mass determination.

For each species present at the area, estimations of relative frequency, relative dominance and relative abundance were done. These variables describe the relationship of each species with others in the same area. The Importance Value Index (I.V.I.), that describes which species are the most important within the studied area, was also determined according to Mueller-Dombois $\&$ Ellenberg (1974) formulas. After these analyses, the areas were compared by the Sørensen's similarity coefficient (1957) using the formula [QS $=2 \mathrm{a} /(\mathrm{b}+\mathrm{c})]$, where $a=$ number of plant species common to areas 1 and $2 ; b=$ total number of species present at area 1;c= total number of species present at area 2 . It was intended to estimate the current degree of weeds similarity between areas after 16 years of distinct management.

Table 1 - Chemical analysis at soil layer of $0-5 \mathrm{~cm}$, under different management systems. Embrapa Western Region Agriculture, Dourados, Brazil

\begin{tabular}{|c|c|c|c|c|c|c|c|c|c|c|c|c|}
\hline \multirow{2}{*}{ System } & $\mathrm{pH}$ & $\mathrm{Al}$ & $\mathrm{K}$ & $\mathrm{Ca}$ & $\mathrm{Mg}$ & CTC & \multirow{2}{*}{\begin{tabular}{|c|} 
O.M. \\
$\left(\mathrm{g} \mathrm{kg}^{-1}\right)$
\end{tabular}} & $\mathrm{P}$ & $\mathrm{Fe}$ & $\mathrm{Mn}$ & $\mathrm{Zn}$ & $\mathrm{Cu}$ \\
\hline & $\left(\mathrm{H}_{2} \mathrm{O}\right)$ & \multicolumn{5}{|c|}{$\left(\mathrm{cmol}_{\mathrm{c}} \mathrm{dm}^{-3}\right)$} & & \multicolumn{5}{|c|}{$\left(\mathrm{mg} \mathrm{dm}^{-3}\right)$} \\
\hline Conventional & 5,84 & 0,18 & 0,53 & 5,52 & 2,18 & 14,2 & 32,3 & 23,1 & 22,8 & 85,3 & 1,7 & 17,5 \\
\hline No-Till & 6,50 & 0,07 & 1,16 & 8,23 & 3,35 & 15,9 & 38,9 & 48,5 & 22,2 & 134,2 & 2,9 & 13,6 \\
\hline Crop-Livestock Integration & 6,30 & 0,05 & 1,01 & 7,51 & 3,50 & 16,0 & 45,4 & 16,9 & 27,0 & 125,2 & 3,1 & 13,3 \\
\hline Livestock & 6,45 & 0,05 & 1,18 & 7,33 & 3,61 & 16,0 & 51,7 & 10,9 & 28,5 & 138,1 & 3,0 & 14,5 \\
\hline
\end{tabular}




\section{RESULTS AND DISCUSSION}

According to the standard deviations, it can be inferred that the area under a weed canopy (black bars in Figure 1) in each management system was $87 \%$ higher for the conventional tillage system in relation to the other ones. Also, as it was to be expected, the presence of some adult forage plants at the soil surface in the area under continuous grazing, allowed it to present only around $30 \%$ of the infestation in comparison to the observed for the average of the other treatments (Figure 1). This is due in part to the shading caused by these adult forage plants (prevention of weed access to sunlight) and also in part due to the almost total absence of soil disturbance in this area in the last 16 years, which probably forced part of the soil seed bank to go into a dormant or quiescent state (Severino, 2005).

The percentage of area covered by a given species, weedy or not, usually determines the richness of the plant community at the area (Townsend et al., 2009). For example, plants with $\mathrm{C}_{4}$ carbon metabolism usually grow faster than plants with $\mathrm{C}_{3}$ carbon metabolism (Taiz \& Zeiger, 2006) under high temperature and radiation availability conditions. Despite this, however, it is known that in a plant community the canopy which is able to develop first and make use of the available space, will determine the composition of species presented in a given weed or mixed plant community (Silva et al., 2007).

The number of plants per square meter followed a distinct tendency of the area covered by weed species (Figure 1). No differences in number of plants was observed between conventional and no-till managements, while crop/livestock integration was intermediary between these two and continuous livestock. It means that in the no-till system, seedlings of weed species were, in rough numbers, $46 \%$ smaller than the ones presented at the conventional tillage area, because a similar number of plants was able to cover a smaller area of soil. In addition, the crop/livestock integration is efficient in help keeping weed species at low level of occurrence as it helped reducing both the number of weed species per area and the size of the canopy of these weed

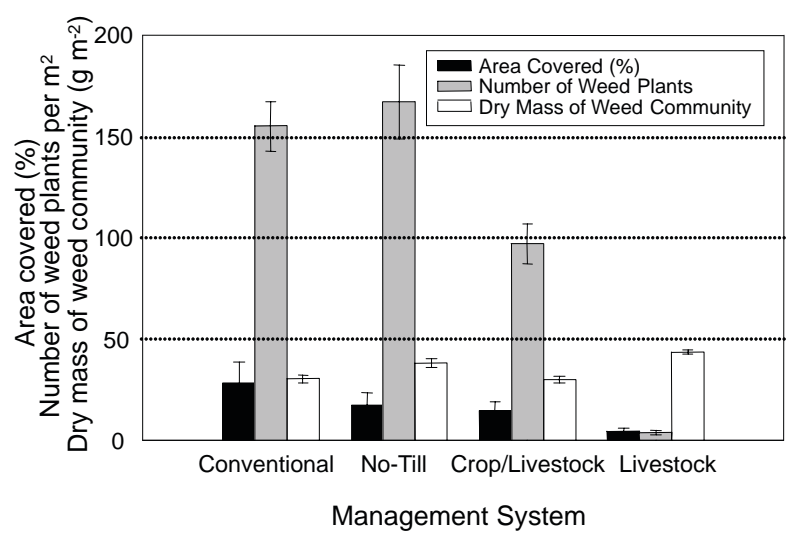

Figure 1 - Percentage of area covered, number of plants from weed species and dry mass of the weedy community in four areas submitted to distinct uses and management for 16 years. Embrapa Western Region Agriculture, Dourados, Brazil.

species as well (Severino, 2005; Gama, 2007). The same was observed for the area under continuous livestock, although at a greater extension (Figure 1).

The dry mass of the weed community showed distinct behavior both in relation to the area covered by the weed species and to the number of plants per area. In general terms, areas submitted to grazing, continuous or at the rotation crop/livestock presented higher sized weed plants, although these plants occurred in much lower numbers. As forage plants are kept in low size due to grazing, weed species which are able to emerge among forage plants usually find plenty of space and sunlight for their development, and dry mass accumulation is usually higher at this environment in comparison to the ones where these plants would have limited access to environmental resources (Belsky, 1992).

At Table 1 it is possible to observe the differences between areas in terms of soil $\mathrm{pH}$, as well as nutrient availability. Although it is not the scope of this work to create a relation between soil chemistry and weeds occurrence, it may help future assessments about weed species needs for nutrients.

In relation to the phytosociological coefficients, at the area under conventional tillage system, Digitaria horizontalis, Avena sativa, Cenchrus echinatus and Brachiaria decumbens were the most abundant species 
(e.g. higher plant number per area) at the soil surface by the time of soil tillage for soybeans planting (Table 2). Weed species with higher frequency of occurrence (more often seen) were in order of appearance $C$. echinatus, $B$. decumbens and $D$. horizontalis. Weed species with higher capacity of dominance under the soil and environmental conditions studied were $A$. sativa, D. horizontalis and C. echinatus (Table 2).

At the area under no-till system, Alternanthera tenella and Commelina benghalensis were the most abundant ones (higher number of plants) and also the most dominant weeds surveyed - the ones which more efficiently used the available space. In addition, these two species were also the most frequently seen together with Ipomoea grandifolia (Table 3).

At the area under periodical crop/livestock rotation, only two weed species were found, being $B$. decumbens the most abundant, dominant and also the most frequently seen (Table 4). It should be highlighted that the area was under crop growth by the time the evaluations were carried out. Based on this, it should be highlighted that in areas where grain crops are rotated with livestock, seedlings of species used as forage may be a potential problem when infesting the crop in succession. Based on this, the choice of a forage species more easily controlled by the pre-planting weed control (usually desiccation) may be important to avoid verifying infestation of the forage species in the successional crop (Severino, 2005).

At the area with continuous livestock, three weed species were collected, being Sonchus oleraceus the most abundant one. However, this species was not the most frequently seen and its frequency of occurrence was similar to the other two species presented at the area: Solanum lycocarpum and Conyza bonariensis. The most abundant species was also the most dominant, followed by $S$. lycocarpum and C. bonariensis (Table 5). Several species are considered as troublesome weeds in pastures, being the most important ones included in one of the following families: Leguminosae, Gramineae, Malvaceae, Myrtaceae, Cyphaceae, Asteraceae,
Cyperaceae, Rubiaceae and Labiateae (Silva \& Dias Filho, 2001; Lara et al., 2003).

Table 2 - Phytosociological coefficients estimated for area submitted to conventional tillage system for 16 years. Embrapa Western Region Agriculture, Dourados, Brazil

\begin{tabular}{|l|r|r|r|r|}
\hline \multicolumn{1}{|c|}{ Weed Species } & $\begin{array}{c}\text { Rel. } \\
\text { Abund. }\end{array}$ & $\begin{array}{c}\text { Rel. } \\
\text { Freq. }\end{array}$ & $\begin{array}{c}\text { Rel. } \\
\text { Dom. }\end{array}$ & I. V. I. \\
\hline Cenchrus echinatus & 12,90 & 25,00 & 16,67 & 54,57 \\
\hline Avena sativa & 26,45 & 12,50 & 31,22 & 70,17 \\
\hline Amaranthus deflexus & 1,94 & 6,25 & 0,13 & 8,32 \\
\hline Brachiaria decumbens & 10,32 & 18,75 & 13,49 & 42,56 \\
\hline Commelina benghalensis & 0,65 & 6,25 & 0,26 & 7,16 \\
\hline Digitaria horizontalis & 40,65 & 18,75 & 22,22 & 81,62 \\
\hline Alternanthera tenella & 6,45 & 6,25 & 10,45 & 23,15 \\
\hline Echinochloa crusgalli & 0,65 & 6,25 & 5,56 & 12,46 \\
\hline Total & 100 & 100 & 100 & 300 \\
\hline
\end{tabular}

Rel. Abund. $=$ relative abundance of the weed species; Rel. Freq. $=$ relative frequency of appearance of the weed species; Rel. Dom. = relative dominance of the weed species; I.V.I. = Importance Value Index of the species based on the three previous parameters.

Table 3 - Phytosociological coefficients estimated for area submitted to no-till system for 16 years. Embrapa Western Region Agriculture, Dourados, Brazil

\begin{tabular}{|l|c|c|c|c|}
\hline \multicolumn{1}{|c|}{ Weed Species } & $\begin{array}{c}\text { Rel. } \\
\text { Abund. }\end{array}$ & $\begin{array}{c}\text { Rel. } \\
\text { Freq. }\end{array}$ & $\begin{array}{c}\text { Rel. } \\
\text { Dom. }\end{array}$ & I. V. I. \\
\hline Commelina benghalensis & 35,33 & 22,22 & 70,71 & 128,26 \\
\hline Alternanthera tenella & 52,69 & 22,22 & 20,55 & 95,47 \\
\hline Euphorbia heterophylla & 0,60 & 11,11 & 0,74 & 12,45 \\
\hline Ipomoea grandifolia & 2,99 & 22,22 & 4,95 & 30,17 \\
\hline Amaranthus deflexus & 5,99 & 11,11 & 2,21 & 19,31 \\
\hline Digitaria horizontalis & 2,40 & 11,11 & 0,84 & 14,35 \\
\hline Total & 100 & 100 & 100 & 300 \\
\hline
\end{tabular}

Rel. Abund. $=$ relative abundance of the weed species; Rel. Freq. $=$ relative frequency of appearance of the weed species; Rel. Dom. = relative dominance of the weed species; I.V.I. = Importance Value Index of the species based on the three previous parameters.

Table 4 - Phytosociological coefficients estimated for area submitted to crop/livestock integration for 16 years. Embrapa Western Region Agriculture, Dourados, Brazil

\begin{tabular}{|l|c|c|c|c|}
\hline \multicolumn{1}{|c|}{ Weed Species } & $\begin{array}{c}\text { Rel. } \\
\text { Abund. }\end{array}$ & $\begin{array}{c}\text { Rel. } \\
\text { Freq. }\end{array}$ & $\begin{array}{c}\text { Rel. } \\
\text { Dom. }\end{array}$ & I. V. I. \\
\hline Brachiaria decumbens & 98,94 & 80,00 & 93,72 & 272,66 \\
\hline Bidens pilosa & 1,06 & 20,00 & 6,28 & 27,34 \\
\hline Total & 100 & 100 & 100 & 300 \\
\hline
\end{tabular}

Rel. Abund. $=$ relative abundance of the weed species; Rel. Freq. $=$ relative frequency of appearance of the weed species; Rel. Dom. = relative dominance of the weed species; I.V.I. = Importance Value Index of the species based on the three previous parameters. 
S. oleraceus and $C$. bonariensis are included in the family Asteraceae.

'It was also observed that the number of species occurring at the crop/livestock integration (Table 4) and continuous livestock (Table 5) was much lower than the one observed in areas more frequently disturbed (Tables 2 and 3), and where rotation with pastures is not used. According to Pandey \& Singh (1991) and Belsky (1992) undisturbed areas tend to have lower species richness than corresponding grazed areas, but the authors also report this change as directly related to the intensity of grazing. In addition, the rotation crop/livestock allows grazing to be used as a complimentary (if not the main) off-season method of weed control by the presence of a more continuous and dense canopy which, among other factors, prevent weed seedlings access to light (Severino, 2005).

Correia \& Durigan (2004) studied the effects of mulching on the emergence of B. decumbens, D. horizontalis, Sida spinosa, I. grandifolia, I. hederifolia and I. quamoclit and found out that shading caused inhibitory effect on seedling emergence of $B$. decumbens and $S$. spinosa, the same being observed for $D$. horizontalis. Besides the physical effect, allelopathy caused by the decomposing straw of forage species is proved to suppress the development of some important weed species (Souza Filho et al., 1997).

Although not identified among the species at the four areas sampled, Gama et al. (2007) reports the Genus Cyperus as one of the most important weeds present in some crop/livestock rotations, highlighting also the importance of the following Genus: Amaranthus, Brachiaria, Cenchrus, Commelina and Euphorbia infesting corn and soybeans
Table 5 - Phytosociological coefficients estimated for area submitted to livestock for 16 years. Embrapa Western Region Agriculture, Dourados, Brazil

\begin{tabular}{|l|c|c|c|c|}
\hline \multicolumn{1}{|c|}{ Weed Species } & $\begin{array}{c}\text { Rel. } \\
\text { Abund. }\end{array}$ & $\begin{array}{c}\text { Rel. } \\
\text { Freq. }\end{array}$ & $\begin{array}{c}\text { Rel. } \\
\text { Dom. }\end{array}$ & I. V. I. \\
\hline Sonchus oleraceus & 50,00 & 33,33 & 44,94 & 128,27 \\
\hline Solanum lycocarpum & 25,00 & 33,33 & 33,92 & 92,25 \\
\hline Conyza bonariensis & 25,00 & 33,33 & 21,14 & 79,47 \\
\hline Total & 100 & 100 & 100 & 300 \\
\hline
\end{tabular}

Rel. Abund. $=$ relative abundance of the weed species; Rel. Freq. $=$ relative frequency of appearance of the weed species; Rel. Dom. = relative dominance of the weed species; I.V.I. = Importance Value Index of the species based on the three previous parameters.

grown in rotation to livestock. All these genuses were identified at least in one of the sampled areas at the long-term trial.

The Sørensen's correlation coefficient indicated similarity of $62 \%$ in relation to weed presence between the area under conventional tillage and the area under notill system after 16 years (Table 6). In addition, similarity was also observed between the conventional system and the area under crop/ livestock integration, although at a much lower level (20\% of similarity). According to Felfili \& Venturoli (2000), similarity indexes above $50 \%$ indicates high similarity between two compared areas. In general terms, areas where pasture was present, continuously or in rotation with crop plants, have showed disconnection from areas where pasture was never used, after 16 years the distinct managements were established (Table 6).

In relation to the Importance Value Index (I.V.I.), D. horizontalis, C. echinatus and $B$. decumbens were the most important species at the area under conventional tillage; $C$. benghalensis and A. tenella were the most important at the no-till area, and

Table 6 - Comparison between areas submitted to distinct uses and managements for 16 years by using the Sørensen's similarity coefficient (QS). Embrapa Western Region Agriculture, Dourados, Brazil

\begin{tabular}{|l|c|c|c|c|}
\hline & Conventional & No-Till & $\begin{array}{c}\text { Crop/Livestock } \\
\text { Integration }\end{array}$ & Livestock \\
\hline Conventional & $\bullet$ & 0,62 & 0,2 & 0 \\
\hline No-Till & $\bullet$ & $\bullet$ & 0 & 0 \\
\hline Crop/Livestock Integration & $\bullet$ & $\bullet$ & $\bullet$ & 0 \\
\hline
\end{tabular}


B. decumbens the most important at the area under crop/livestock rotation. It is important to highlight that for the area under continuous grazing, weeds appeared very occasionally and the I.V.I. tended to overestimate the importance of these species at this area.

In general terms, areas where pasture and grazing were not present, exhibited a number of weed seedlings $250 \%$ higher than areas periodically or continuously under grazing after 16 years of distinct management, while the area of soil covered by weeds was $87 \%$ superior at the conventional tillage system in relation to the average of other treatments. In addition, grass weeds were the most important at the conventional tillage area while broadleaved weeds where more important at the no-till area. Besides lightrelated factors, this is hypothesized to be due to a lower susceptibility of these weed species to the herbicide used for pre-planting desiccation, which may cause a selection of weed species. Under crop/livestock integration, there may be the need to care about controlling seedlings of the forage species inside grain crops in succession, and consequently avoid growing as a forage species with high tolerance to herbicides like the glyphosate.

\section{ACKNOWLEDGEMENTS}

The authors thank FINEP/MCT for financing the Prodesilp project.

\section{LITERATURE CITED}

AMARAL, J. A. M. et al. Levantamento semidetalhado dos solos do campo experimental de Dourados, da Embrapa Agropecuária Oeste, município de Dourados, MS. Dourados: Embrapa Agropecuária Oeste; Rio de Janeiro: Embrapa Solos, 2000. 68 p. (Embrapa Agropecuária Oeste. Documentos, 22; Embrapa Solos. Documentos, 15)

BELSKY,A. J. Effects of grazing, competition, disturbance and fire on species composition and diversity in grassland communities. J. Vegetation Sci., v. 3, n. 2, p. 187-200, 1992.

BULHER, D. D.; MESTER, T. C.; KOLHER, K. A. The effect of maize residues and tillage on emergence of Setaria faberi, Abutilon theophrasti, Amaranthus retroflexus e Chenopodium album. Weed Res., v. 36, n. 2, p. 153-165, 1996.
CORREIA, N. M.; DURIGAN, J. C. Emergência de plantas daninhas em solo coberto com palha de cana-de-açúcar.

Planta Daninha, v. 22, n. 1, p. 11-17, 2004.

DEUBER, R. Ciência das plantas daninhas:

fundamentos. Jaboticabal: Funep, 1992. v. 1. 431 p.

FELFILI, J. M.; VENTUROLI, F. Tópicos em análise de vegetação. Comunicações Técnicas Flor., v. 2 n. 2, p. 34, 2000 .

FIETZ, C. R.; FISCH, G. F. O clima da região de Dourados, MS. Dourados: Embrapa Agropecuária Oeste, 2006. 32 p. (Embrapa Agropecuária Oeste. Documentos, 85).

GAMA, J. C. M.; JESUS, L. L.; KARAM, D. Fitossociologia de plantas espontâneas em sistemas de integração lavoura/ pecuária. R. Bras. Agroecol., v. 2, n. 2, p. 929-932, 2007.

GOMES, G. L. G.. C. et al. Cadastramento fitossociológico de plantas daninhas na bananicultura. Planta Daninha, v. 28, n. 1, p. $61-68,2010$

GOMES, F. G.; CHRISTOFFOLETI, P. J. Biologia e manejo de plantas daninhas em áreas de plantio direto.

Planta Daninha, v. 26, n. 4, p. 789-798, 2008.

GUREVITCH, J.; SCHEINER, S. M.; FOX, G. A. Ecologia vegetal. Porto Alegre: Artmed, 2009. 592 p.

LARA, J. F. R.; MACEDO, J. F.; BRANDÃO, M. Plantas daninhas em pastagens de várzeas do estado de Minas Gerais. Planta Daninha, v. 21, n. 1, p. 11-20, 2003.

MUELLER-DOMBOIS, D.; ELLENBERG, H. Aims and methods of vegetation ecology. New York: Wiley, 1974. $547 \mathrm{p}$.

NORSWORTHY, J. K.; BURGOS, N. R.; OLIVER, L. R. Differences in weed tolerance to glyphosate involve different mechanisms. Weed Technol., v. 15, n. 4, p. 725-731, 2001.

PANDEY, C. B.; SINGH, J. S. Influence of grazing and soil conditions on secondary savanna vegetation in India. J. Veget. Sci., v. 2, n. 1, p. 95-102, 1991.

SEVERINO, F. J. Supressão da infestação da plantas daninhas pelo sistema de produção de integração lavoura-pecuária. 2005. 113 f. Tese (Doutorado em Agronomia) - Escola Superior de Agricultura "Luiz de Queiroz", Piracicaba, 2005

SILVA, D. S. M.; DIAS FILHO, M. B. Banco de sementes de plantas daninhas em solo cultivado com pastagens de Brachiaria brizantha e Brachiaria humidicola de diferentes idades. Planta Daninha, v. 19, n. 2, p. 179-185, 2001.

Planta Daninha, Viçosa-MG, v. 29, n. 3, p. 515-522, 2011 
SILVA, A. A. et al. Biologia de plantas daninhas. In: SILVA A. A.; SILVA, J. F. (Eds.). Tópicos em manejo de plantas daninhas. Viçosa, MG: Universidade Federal de Viçosa, 2007. p. $17-61$.

SØRENSEN, T. A method of establishing groups of equal amplitude in plant sociology based on similarity of species and its application to analyses of the vegetation on Danish commons. Biologiske Skrifter, v. 5 n. 4, p. 1-34, 1957.

SOUZA FILHO, A. P. S.; RODRIGUES, L. R. A.; RODRIGUES, T. J. D. Potencial alelopático de forrageiras tropicais: efeitos sobre invasoras de pastagens

Planta Daninha, v. 15, n. 1, p. 53-60, 1997.
TAIZ, L.; ZEIGER, E. Plant physiology. Sunderland: Sinauer, 2006. 705 p.

TOWNSEND, C. R.; PEREIRA, R. G. A.; COSTA, N. L. Considerações sobre sistemas de integração lavoura/pecuária na Amazônia. Porto Velho: Embrapa Rondônia, 2009. 29 p. (Embrapa Rondônia. Documentos, 130)

VOLL, E. et al. A dinâmina das plantas daninhas e práticas de manejo. Londrina: Embrapa Soja, 2005. 85 p (Embrapa Soja. Documentos, 260). 